\title{
STRATEGI IMPLEMENTASI KEBIJAKAN TENTANG PROGRAM KAMPUNG KELUARGA BERENCANA MENUJU KELUARGA SEJAHTERA DI KABUPATEN CIREBON
}

\author{
Lia Muliawaty \\ Jurusan Administrasi Negara FISIP Universitas Pasundan \\ lia.muliawaty@unpas.ac.id \\ Maharto \\ Dinas KUKM Pemerintah Kabupaten Cirebon \\ mahartoisnanto@gmail.com
}

DOI: http://dx.doi.org/10.23969/decision.v1i2.1878

\begin{abstract}
Since the birth of the family planning program in Indonesia, many have produced significant results and influences on population control and growth. The indications seen in the implementation of policies on the family planning village program have not been effective including slum environmental facilities, the achievement of long-term contraception is still low, family development activities are not optimal, lack of evaluation and reporting and lack of maximum coordination from relevant agencies, limited number of managers / extension workers, community participation is still low and limited supporting facilities, lack of guidance to community institutions, lack of socialization of prosperous families, and response from program managers has not been maximized. The research method used is a qualitative method, which means that research is to understand phenomena about what is experienced by research subjects holistically and by means of descriptions in the form of words and language in a particular context experienced by utilizing various scientific methods. The type of qualitative approach in this research is a case study. The implementation of policies on the family planning village program towards a prosperous family in Cirebon Regency has not yet been realized, due to the content of policy and the context of implementation which have not been maximized. An effective strategy to be able to optimize the implementation of policies on the village family planning program towards the realization of a prosperous family in Cirebon Regency is to tend to a strategy of deversification or ST strategy, wherein this strategy uses or utilizes power to overcome the threats faced, by innovating adding other programs so as not to saturated.
\end{abstract}

Keywords: Policy implementation, KB Village, Family Welfare.

\begin{abstract}
Abstrak
Sejak bergulirnya program keluarga berencana di Indonesia, sudah banyak membuahkan hasil dan pengaruh yang signifikan terhadap pengendalian dan pertumbuhan penduduk. Indikasi yang terlihat dalam implementasi kebijakan tentang program kampung keluarga berencana belum efektif diantaranya sarana lingkungan yang kumuh, pencapaian kontrasepsi jangka panjang masih rendah, kegiatan bina keluarga yang belum maksimal, kurangnya evaluasi dan pelaporan serta kurang maksimalnya koordinasi dari instansi terkait, keterbatasan jumlah pengelola/penyuluh, partisipasi masyarakat masih rendah serta keterbatasan sarana pendukung, kurangnya pembinaan terhadap institusi masyarakat, kurangnya sosialisasi keluarga sejahtera, dan respon dari pengelola program belum maksimal. Metode penelitian yang digunakan
\end{abstract}


adalah metode kualitatif, yang berarti bahwa penelitian untuk memahami fenomena tentang apa yang dialami oleh subyek penelitian secara holistik dan dengan cara deskripsi dalam bentuk kata-kata dan bahasa pada suatu konteks khusus yang dialami dengan memanfaatkan berbagai metode ilmiah. Jenis pendekatan kualitatif dalam penelitian ini adalah studi kasus. Implementasi kebijakan tentang program kampung keluarga berencana menuju keluarga sejahtera di Kabupaten Cirebon belum terwujud, disebabkan oleh faktor content of policy (isi kebijakan) dan context of implementation (konteks implementasi) yang belum maksimal. Strategi yang efektif untuk dapat mengoptimalkan implementasi kebijakan tentang program kampung keluarga berencana menuju terwujudnya keluarga sejahtera di Kabupaten Cirebon adalah cenderung ke strategi deversifikasi atau strategi $\boldsymbol{S T}$, dimana dalam strategi ini menggunakan atau memanfaatkan kekuatan untuk mengatasi ancaman yang dihadapi, dengan inovasi menambah program lain supaya tidak jenuh.

\section{Kata kunci: Implementasi kebijakan, Kampung KB dan Keluarga Sejahtera.}

\section{PENDAHULUAN}

\subsection{Latar Belakang Penelitian}

Indonesia sebagai negara berkembang dengan ciri-ciri penduduk meliputi : (1) jumlah penduduk yang relatif besar dengan tingkat pertumbuhan yang tinggi, (2) struktur umur yang muda, dan (3) penyebaran yang tidak merata. Indikator keberhasilan pembangunan dapat dilihat sampai sejauhmana pembangunan tersebut berdampak kepada penduduknya dan parameternya adalah IPM (Indeks Pembangunan Manusia).

Hasil pengamatan dan fakta di Kabupaten Cirebon dihadapkan kepada faktor internal dan eksternal dalam implementasi kebijakan tentang program Kampung Keluarga Berencana, berbagai indikasi permasalahan diantaranya :

1) Penataan lingkungan yang belum teratur diantaranya jalan-jalan gang ada yang terlalu sempit menyulitkan untuk akses transfortasi serta masih adanya sarana lingkungan yang kumuh dan rumah tidak layak huni.

2) Pemahaman dan pengetahuan $\mathrm{KB}$ secara umum masyarakat sudah memahami, tetapi pemahaman tentang kontrasepsi jangka panjang masih rendah.
3) Evaluasi dan pelaporan kegiatan masih belum optimal, tentunya akan sulit untuk menentukan langkah-langkah yang akan ditempuh.

4) Jumlah petugas lini lapangan yang tidak memadai, yaitu Petugas KB termasuk Tenaga Penggerak Desa (TPD) bidang keluarga berencana membina 2-3 desa.

5) Sarana dan prasarana masih belum optimal.

6) Kurangannya penbinaan terhadap institusi masyarakat yang berkesinambungan.

7) Sosialisasi keluarga sejahtera terhadap masyarakat belum optimal.

8) Respon dari Pokja Kampung KB terhadap gejala ataupun keluhan masyarakat kurang maksimal.

Fokus dalam penelitian ini adalah kebijakan Program Kampung KB belum dapat menurunkan angka kelahiran, fakta menunjukkan implementasi kebijakan Program Kampung KB di Kabupaten Cirebon belum efektif, sehingga Peneliti tertarik untuk melakukan kajian ilmiah melalui fokus penelitian mengenai implementasi kebijakan Program Kampung KB menuju terwujudnya keluarga sejahtera di Kabupaten Cirebon, dimaksudkan : 
1) Mengetahui, mendiskripsikan dan menganalisis faktor penghambat implementasi kebijakan program Kampung KB di Kabupaten Cirebon dengan pendekatan faktor yang mempengaruhi keberhasilan implementasi kebijakan yang dikemukakan oleh Grindle, yaitu isi kebijakan (content of policy) dan konteks implementasi (context of implementation).

2) Menentukan langkah-langkah strategis agar implementasi kebijakan tentang program Kampung Keluarga Berencana menuju keluarga sejahtera di Kabupaten Cirebon menjadi terwujud, dengan menggunakan metode analisis SWOT.

\subsection{Rumusan Masalah Penelitian}

Berdasarkan latar belakang penelitian tersebut, maka Peneliti dapat mengajukan problem statement (pernyataan masalah) penelitian sebagai berikut : "Strategi Implementasi kebijakan tentang program Kampung Keluarga Berencana menuju keluaarga sejahtera di Kabupaten Cirebon masih belum efektif, sehingga pelaksanaan menuju keluarga yang sejahtera belum terwujud "

Mengacu pada pernyataan masalah tersebut, maka Peneliti menyampaikan rumusan masalah sebagai berikut :
1) Faktor-faktor apa yang menyebabkan Implementasi Kebijakan tentang program Kampung Keluarga Berencana di Kabupaten Cirebon menuju keluarga sejahtera belum terwujud?

2) Strategi apa yang diterapkan agar implementasi kebijakan tentang program Kampung Keluarga Berencana menuju keluarga sejahtera di Kabupaten Cirebon menjadi terwujud?

\subsection{Maksud Penelitian}

Penelitian ini mengandung maksud untuk mengkaji dan melakukan analisis secara mendalam serta melakukan analisa data yang berhubungan dengan implementasi kebijakan tentang program Kampung Keluarga Berencana di Kabupaten Cirebon dalam pengendalian kelahiran untuk mewujudkan keluarga yang sejahtera.

a) Mengetahui, mendiskripsikan serta menganalisis faktor-faktor apa yang menyebabkan implementasi kebijakan program Kampung Keluarga Berencana menuju keluarga sejahtara di Kabupaten Cirebon belum terwujud.

b) Menentukan langkah-langkah strategi, agar implementasi kebijakan program Kampung Keluarga Berencana (KB) menuju keluarga sejahtera di Kabupaten Cirebon menjadi terwujud.

\subsection{Kegunaan Penelitian}

1) Secara Teoritis

Untuk mengembangkan teori-teori tentang implementasi kebijakan serta diharapkan memberikan sumbangan penelitian bagi perkembangan ilmu administrasi publik umumnya, khususnya memberikan sumbangan pemikiran tentang program kampung keluarga berencana.

\section{2) Secara Praktis}

Diharapkan dari penelitian ini dapat memberikan masukan secara konseptual dan dapat memberikan konstribusi kepada Pemerintah Kabupaten Cirebon dalam menyusun dan menerapkan strategi implementasi kebijakan tentang program Kampung Keluarga Berencana. 


\subsection{Kajian Pustaka}

Syarat-syarat yang mempengaruhi implementasi kebijakan dimana suatu proses pelaksanaan kebijakan memperhatikan kondisi baik secara internal maupun eksternal organisasi. Dunn (2000:56) menyatakan bahwa : "Policy implementation it is values the execution and steering of a laws of action overtime. Policy implementation is essentially a practical activity, as distinguished from policy formulation, which is essential theoretic".

Pendapat tersebut dapat peneliti jelaskan bahwa Implementasi Kebijakan adalah menilai pelaksanaan kebijakan dalam suatu kemudi yang melebihi tindakan hukum. Implementasi Kebijakan sangat utama untuk suatu aktivitas praktis, seperti dibedakan dari perumusan kebijakan, yang mana adalah teoritis penting. Sehubungan dengan sifat praktis yang ada dalam proses implementasi kebijakan, maka hal yang wajar bahwa implementasi ini berkaitan dengan proses politik dan administrasi. Hal ini disebabkan karena ia menyangkut tujuan dari ditiadakannya kebijakan tersebut. Meter dan Horn dalam Islamy (2001:65) menyatakan bahwa implementasi kebijakan sebagai "Those action by public policy or private individuals (or groups) that are directed at the achievement of objectives set forth in prior policy decision".

Tindakan-tindakan yang dilakukan baik oleh individuindividu/pejabat-pejabat atau kelompok-kelompok pemerintah atau swasta yang diarahkan kepada tercapainya tujuan-tujuan yang telah digariskan dalam keputusan kebijakan. Pandangan tersebut dimaksudkan tidak lain adalah bahwa kebijakan merupakan tindakan yang diarahkan dalam kerangka mencapai tujuan bersama. Pelaksanaan suatu kebijakan gagal, maka timbullah pertanyaan tentang sebab-musababnya. Pengetahuan tentang sebab musabab ini dapat memberi titik-titik pertemuan yang penting mengenai cara bagaimana pelaksanaan dapat dikembangkan. Sebab-musabab yang mungkin menjadi dasar dari kegagalan pelaksanaan kebijakan, sangat berbeda-beda satu sama lain. Sebab-musabab ini ada sangkut pautnya berturut-turut dengan isi dari kebijakan yang harus dilaksanakan, tingkat informasi dari aktor-aktor yang terlibat dalam pelaksanaan, banyaknya dukungan bagi pelaksanaan, banyaknya dukungan bagi kebijakan yang harus dilaksanakan dan akhirnya pembagian dari potensipotensi yang ada (struktur organisasi, perbandingan kekuasaan dan seterusnya).

Aspek-aspek yang dapat mempengaruhi terhadap kebijakan menurut Hoogerwerf (2003:168), yaitu :

1. Isi Kebijakan ; Isi dari kebijakan yang akan dilaksanakan dapat mempersulit pelaksanaannya dengan berbagai cara. Beberapa pokok utama adalah sebagai berikut: Pelaksanaan pertamatama dapat gagal karena samarsamar isi dari banyak kebijakan (tujuan-tujuan tidak cukup terperinci, sarana-sarana dan penetapan prioritas, program kebijakan yang terlalu umum atau sama tidak ada). Isi kebijakan yang samara-samar sering akan mengakibatkan kurangnya pegangan bagi para pelaksana, yang akan memperbesar kemungkinan interprestasi yang berbeda-beda dari system kebijakan. Terlebih jika rantai pelaksanaan panjang, maka kemungkinan pergeseran tujuan lebih besar. 
2. Informasi ; Pelaksanaan suatu kebijakan memperkirakan, bahwa actor-aktor yang terlibat langsung, mempunyai informasi yang perlu untuk dapat memainkan perannya dengan baik, informasi itu sering tidak ada sebagai akibat gangguan dalam struktur komunikasi. Juga masalah-masalah dapat meruncing, karena struktur komunikasi yang serba kurang antara organisasi pelaksana dan objek kebijakan.

3. Dukungan ; Pelaksanaan suatu kebijakan akan sangat dipersulit jika pada pelaksanaan tidak cukup dukungan untuk kebijakan ini. Dalam hal ini memainkan peranan juga kepentingan sendiri dan tujuan dari pelaksanaan, juga pengharapan-pengharapan mereka tentang efektivitas sarana-sarana yang dipilih, kesungguhan dan situasi masalah, latar belakang historis, tradisi dan kebiasaan kebiasaan rutin juga pendapatpendapat mengenai cara bagaimana pelaksanaan harus diorganisasikan. Kekurangan dukungan dapat dilihat dari cara pelaksana memanfaatkan kebebasan kebijakan mereka. Selain itu juga kurang kesediaan objek-objek kebijakan untuk bekerja sama pada pelaksanaan kebijakan.

4. Pembagian Potensi ; Dalam hal ini adalah pembagian potensi di antara aktor-aktor yang terlibat dalam pelaksaan. Mengenai organisasi pelaksana maka dalam hubungan ini antara lain tingkat deferensiasi dari tugas-tugas dan wewenang sangat penting. Struktur dari organisasi pelaksana dapat juga mengakibatkan masalah-masalah, apabila pembagian wewenang dan tanggung jawab kurang disesuaikan dengan pembagian tugas atau ditandai oleh pembatasan-pembatasan yang kurang jelas.

Aspek-aspek kebijakan sebagaimana disebutkan di atas merupakan serangkaian yang tidak dapat terpisahkan baik itu isi kebijakan, informasi, dukungan maupun pembagian potensi merupakan aspek yang mempengaruhi kelancaran implementasi. Hoogerwerf (2003:169) mengatakan bahwa "Implementasi pertama-tama dapat gagal karena samarsamar isi dari banyak kebijakan (tujuan tidak cukup terperinci, sarana-sarana dan penetapan prioritas, program kebijakan yang terlalu umum atau sama sekali tidak ada". Isi kebijakan harus jelas, karena isi kebijakan yang samarasamar akan salah pemahaman ketika implementasinya. Secara rinci Hoogerwerf (2003:169) menyebutkan bahwa :

"Isi kebijakan yang
samar-samar sering akan
mengakibatkan kurangnya
pegangan bagi para
pelaksana, yang akan
memperbesar
kemungkinan interpretasi
yang berbeda-beda dari
isi kebijakan, terlebih jika
rantai pelaksanaan
panjang, maka kemungkinan pergeseran tujuan yang lebih besar. Jika kebijakan masih dapat kekurangan, akhirnya akan menimbulkan kelonggaran yang menjembatani mengelakan objek-objek kebijakan terhadap kewajibannya.

Ketidaklengkapan isi kebijakan dapat terjadi karena tidak memuat 


\section{bersifat teknis atau belum di atur".}

Isi kebijakan dapat memberikan kejelasan terhadap pelaksanaan suatu kebijakan. Pelaksana yang jauh dari pusat ada kemungkinan tidak mengetahui kehendak para atasannya. Sebaliknya aktor pada tahap atas tidak mengetahui atau kurang memahami masalah-masalah yang dihadapi aktor bawah dan tidak mengetahui pula pemecahan masalah yang paling tepat. Hoogerwerf (2003:170) menyatakan bahwa : ".... Harus terdapat struktur komunikasi yang mampu memperlancar arus informasi baik antar pelaksana dan antara pelaksana dengan objek kebijakan", informasi akan mudah mengakibatkan gambaran yang kurang lengkap atau kurang tepat baik pada objek kebijakan maupun pada pelaksana".

Keberadaan Kampung Keluarga Berencana yang seyogyanya menjadi ikon atau miniatur program kependudukan dan keluarga berencana di suatu wilayah akan bernasib sama dengan kampung-kampung lain yang belum ada program Kampung Keluarga Berencana di wilayanya. Kerana ada beberapa faktor dari isi kebijakan maupun konteks implementasi yang belum efektif.

Konsep implementasi kebijakan yang dikemukakan oleh Edwards III, dimana keberhasilan impelementasi kebijakan dipengaruhi oleh empat faktor yaitu communication (komunikasi), resources (sumber daya), disposition (disposisi) dan bureaucratic structure (struktur birokrasi).

Konsep yang dikemukakan oleh Grindle (1980) adalah sebuah kebijakan sangat bergantung pada faktor content of policy dan faktor context of implementation, lebih lengkapnya adalah sebagai berikut :

\section{Content Of Policy (Isi Kebijakan)}

a. Interest Affected (Kepentingan yang dipengaruhi kebijakan).

b. Type of Benefits (Jenis manfaat yang dihasilkan).

c. Extent Of Change Envisioned (Perubahan yang diinginkan).

d. Site of Decision Making (Kedudukan pembuat kebijakan).

e. Program Implementors (Pelaksana Program)

f. Resources Commited (Sumber daya yang dikerahkan)

\section{Context Of Implementation} (Konteks Implementasi)

a. Power, Interest and Strategies Of Actors Involved (Kekuasaan, kepentingan dan strategi aktor yang terlibat)

b. Institution and Regime Characteristics (Karakteristik lembaga dan penguasa)

c. Compliance and Responsiveness (Kepatuhan dan daya tanggap)

Kerangka berfikir dalam penelitian ini dapat digambarkan dalam bagan sebagai berikut:

Gambar 1. : Bagan Kerangka Berfikir

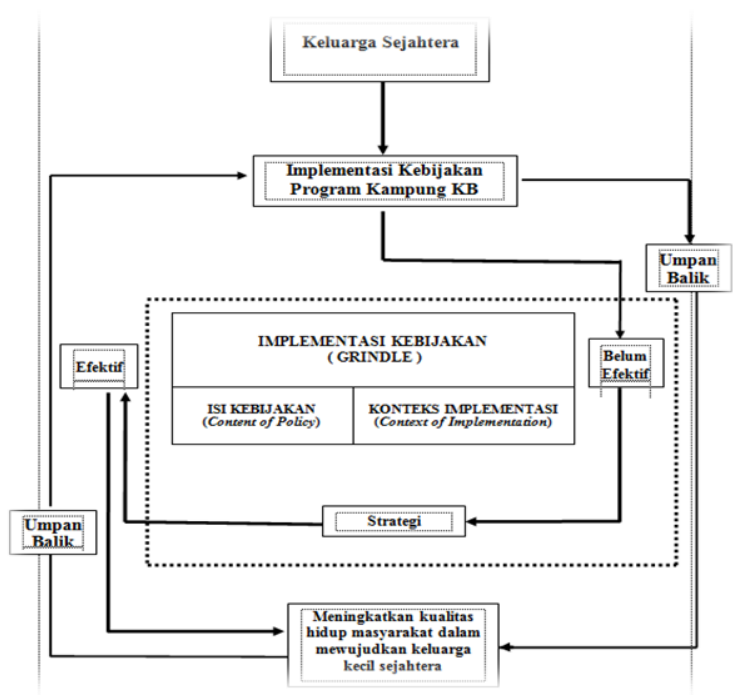


Preposisinya adalah sebagai berikut:

1) Faktor content of policy (isi kebijakan) dan context of implementation (konteks implementasi) yang belum efektif, menyebabkan implementsi kebijakan Program Kampung Keluarga Berencana menuju keluarga sejahtera di Kabupaten Cirebon belum terwujud.

2) Penerapan strategi deversifikasi konsentris untuk mengatasi kelemahan dan ancaman dalam implementasi kebijakan tentang program Kampung Keluarga Berencana menuju terwujudnya keluarga sejahtera di Kabupaten Cirebon.

\subsection{Objek Penelitian}

Lokasi penelitian ini dilakukan di Kabupaten Cirebon yaitu Kecamatan Gunungjati, Kecamatan Plumbon, Kecamatan Arjawinangun dan Kecamatan Greged. Penentuan lokasi kecamatan tersebut disamping didalamnya masih ada permasalahan tentang pelaksanaan program Kampung $\mathrm{KB}$, juga mewakili daerah utara, timur dan selatan, barat serta wilayah berdasarkan karakteristik masyarakatnya yaitu daerah pantai, daerah pegunungan dan daerah dataran rendah.

\subsection{Metode Penelitian}

Metode penelitian yang digunakan dalam penelitian ini adalah pendekatan kualitatif dengan metode deskriptif analisis. Konsep metode penelitian kualitatif menurut Moleong adalah : penelitian yang bermaksud untuk memahami fenomena tentang apa yang dialami oleh subyek penelitian misalnya perilaku, persepsi, motivasi, tindakan dan lain-lain secara holistik dan dengan cara deskripsi dalam bentuk kata-kata dan bahasa pada suatu konteks khusus yang alamiah dan dengan memanfaatkan berbagai metode ilmiah. Jenis pendekatan kualitaif dalam penelitian ini cenderung ke analisis studi kasus, peneliti penyelidiki secara cermat suatu program, peristiwa, aktivitas, proses atau sekelompok individu

Analisis SWOT merupakan instrument perencanaan strategis dengan menggunakan kerangka kerja kekuatan dan kelemahan serta peluang dan ancaman. Analisa SWOT ini terdiri atas empat komponen dasar yaitu :

$\mathbf{S}=$ (Strengths/Kekuatan)

Adalah situasi atau kondisi yang merupakan kekuatan dari organisasi atau program pada saat ini.

$\mathbf{W}=$ (Weaknesses $/$ Kelemahan $)$

Adalah situasi atau kondisi yang merupakan kelemahan dari organisasi atau program pada saat ini.

\section{$\mathbf{O}=($ Opportunites/ Peluang $)$}

Adalah situasi atau kondisi yang merupakan peluang di luar organisasi dan memberikan peluang berkembang bagi organisasi di masa depan.

\section{$\mathbf{T}=$ (Threats/Ancaman)}

Adalah situasi yang merupakan ancaman bagi organisasi yang datang dari luar organisasi dan dapat mengancam eksistensi organisasi di masa depan.

Analisis SWOT digambarkan dalam diagram yang memiliki 4 kuadran, setiap kuadran merupakan sebuah strategi yang akan dilaksanakan dalam upaya pencapaian tujuan Kampung KB untuk untuk mewujudkan keluarga yang sejahtera :

Gambar 2. : Diagram Analisis SWOT

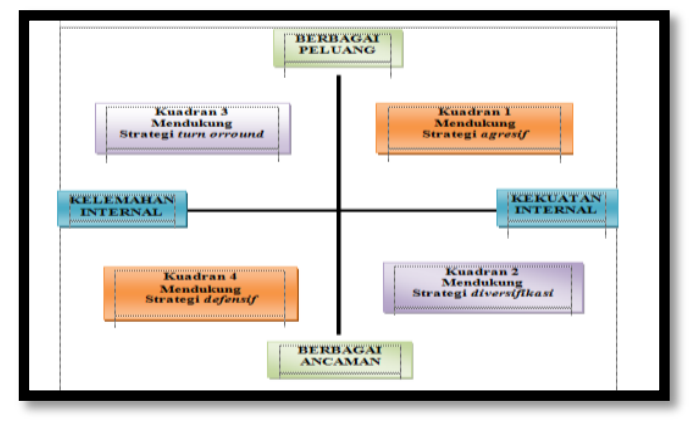

Sumber: Rangkuti (2016 : 20) 


\subsection{Pembahasan}

Berdasarkan data tahun 2017 keluarga pra sejahtera masih cukup tinggi yaitu sejumlah 389.963 keluarga atau 57,59 $\%$ yang terdiri dari pra sejahtera 196.141 keluarga dan keluarga sejahtera tahap I sejumlah 193.822 keluarga. Sedangkan Tahun 2014 sebelum pembentukan Kampung Keluarga Berencana (KB) adalah sebesar 386.531 atau $60,41 \%$. Program Kampung Keluarga Berencana (KB) secara umum memang sudah berdampak terhadap kegiatan kependudukan dan Keluarga Berencana, namun belum banyak berpengaruh perhadap peningkatan kesejahteraan keluarga. Keluarga pra sejahtera dan keluarga sejahtera I pada Tahun 2014 sampai dengan Tahun 2017 masih cukup tinggi.

Upaya untuk meningkatkan kesejahteraan keluarga adalah dengan peningkatan pendapatan, sedangkan peningkatan pendapatan kalau tidak diimbangi dengan pengaturan jumlah anak yang ideal akan mengalami kesulitan dalam menata perekonomian keluarga. Peserta KB dengan metode jangka panjang tentunya keefektifannya lebih banyak apabila dibandingkan dengan metode kontrasepsi non jangkan panjang. Pencapaian metode kontrasepsi jangka panjang di Kabupaten Cirebon masih cukup rendah, hal ini kalau tidak ditangani dan disikapi secara serius akan mengakibatkan banyak pasangan usia subur yang kurang terlindungi.

Kegiatan bina keluarga dan UPPKS tersebut tidak ada perkembangan yang signifikan dari Tahun 2014, kegiatan bina keluarga dan UPPKS dapat meningkatkan ketahanan keluarga melalui 8 fungsi keluarga, mencakup : fungsi keagamaan. fungsi sosial budaya, fungsi cinta dan kasih sayang, fungsi perlindungan, fungsi reproduksi, fungsi sosialisasi dan pendidikan, fungsi ekonomi, fungsi lingkungan masih belum optimal.

Hasil observasi, FGD dan wawancara dari berbagai sumber atau elemen yang Peneliti lakukan menggunakan metode tringulasi sumber dan hasil observasi di lapangan, faktor content of policy (isi kebijakan) dalam implementasi kebijakan tentang program Kampung KB menuju terwujudnya keluarga sejahtera di Kabupaten Cirebon masih ada beberapa kelemahan diantaranya :

1) Di beberapa wilayah masih diperlukan penataan sarana kesehatan lingkungan, hal ini dilakukan agar masyarakat membuang sampah pada tempatnya, agar sesuai dengan Perda Kabupaten Cirebon Nomor 7 Tahun 2012 tentang Persampahan serta masih adanya rumah tidak layak huni.

2) Program Kampung KB diharapkan dapat mendongkrak pencapaian peserta $\mathrm{KB}$ jangka panjang mencapai lebih dari 50\%, sedangkan kondisi yang ada pencapaian peserta KB metode jangka panjang berdasarkan evaluasi dan Rakerda Tahun 2017 masih sangat rendah yaitu $15,66 \%$.

3) Kegiatan bina keluarga masih belum sepenuhnya dilaksanakan dengan maksimal.

4) Evaluasi dan pelaporan yang dilakukan oleh petugas dalam kegitan program Kampung KB masih belum dilakukan dengan optimal.

5) Kurangnya koordinasi diantara Tim Koordinasi Kampung KB.

6) Jumlah pengelola atau petugas KB di lini lapangan sangat sedikit, hal ini disebabkan karena banyak yang pensiun dan belum adanya penambahan. 
7) Pokja Kampung $\mathrm{KB}$ belum melakukan kegiatan secara rutin dan mandiri, kegiatan dilakukan apabila ada instruksi.

8) Pemberian dukungan sarana oleh Tim Koordinasi Kampung KB / Instansi terkait masih belum memadai dalam mensukseskan program Kampung KB.

9) Partisipasi masyarakat dalam kegiatan Kampung KB masih belum maksimal.

Berdasarkan wawancara dari berbagai unsur dan $F G D$ yang Peneliti lakukan, dengan menggunakan tringulasi sumber dan observasi lapangan. Faktor context of implementation (konteks implementasi) dalam implementasi kebijakan tentang program Kampung KB menuju terwujudnya keluarga sejahtera di Kabupaten Cirebon masih ada kelemahan di beberapa sektor, diantaranya :

1) Masih kurangnya pembinaan institusi masyarakat secara berkesinambungan, pembinaan masih dilakukan hanya pada saat ada kegiatan.

2) Kurangnya sosialisasi tentang keluarga sejahtera.

3) Kurangnya respon dan kepekaan terhadap lingkungan, hal itu terjadi karena masih belum melakukan penjaringan dan menampung aspirasi dari masyarakat.

Berdasarkan uraian diatas, faktor-faktor yang mempengaruhi implementasi kebijakan yang dikemukakan oleh Grindle, Peneliti temukan juga dalam penelitian implementasi kebijakan tentang program Kampung KB yang Peneliti lakukan. Menurut Peneliti content of policy (isi kebijakan) maupun context of implementation (konteks implementasi) yang dikemukakan oleh Grindle lebih banyak berkaitan dengan pelaksana program. Kepentingan, manfaat, sumber daya, maka model implementasi kebijakan Grindle ini sangat tepat untuk menganalisis implementasi kebijakan tentang program Kampung Keluarga Berencana menuju terwujudnya keluarga sejahtera di Kabupaten Cirebon, dimana kelemahan utamanya adalah pada aspek pelaksana program, koordinasi dengan instansi terkait dan partisipasi masyarakat.

Implementasi kebijakan tentang program Kampung Keluarga Berencana di Kabupaten Cirebon tidak dapat dihindari dari berbagai kepentingan, pemanfaatan dari hasil kebijakan, perubahan yang diharapkan, letak pembuat kebijakan, peran dari pejabat pelaksana, serta sumber daya yang dikerahkan.

Hal lain yang sangat berpengaruh dalam implementasi kebijakan adalah kekuasaan, kepentingan dan strategi aktor yang terlibat, karakteristik lembaga dan penguasa serta kepatuhan dan daya tanggap. Implementasi kebijakan kampung KB tidak terlepas dari berbagai faktor yang mempengaruhi, mencakup faktor internal dan faktor eksternal seperti lingkungan, sosial, ekonomi dan budaya.

Faktor-faktor yang Menyebabkan Implementasi Kebijakan Tentang Program Kampung KB Menuju Keluarga Sejahtera di Kabupaten Cirebon Belum Terwujud.

1) Kurang adanya upaya untuk meningkatkan derejat kesehatan lingkungan.

2) Pencapaian peserta KB MJP masih rendah.

3) Kegiatan bina keluarga belum maksimal.

4) Kurangnya evaluasi dan pelaporan.

5) Koordinasi dengan instansi terkait kurang maksimal.

6) Jumlah petugas KB kurang memadai. 
7) Kegiatan Pokja Kampung KB belum maksimal

8) Terbatasnya sarana pendukung.

9) Partisipasi masyarakat tidak optimal.

10) Pembinaan institusi tidak berkesinambungan.

11) Kurangnya sosialisasi keluarga sejahtera.

12) Respon pelaksana terhadap program belum optimal.

Analisis SWOT Implementasi

Kebijakan Tentang Program Kampung KB Menuju Terwujudnya Keluarga Sejahtera di Kabupaten Cirebon.

Analisis SWOT adalah analisis terhadap faktor-faktor strength (kekuatan), weakness (kelemahan), opportunity (peluang) dan threat (ancanam) yang dihadapi oleh suatu organisasi. Analisis SWOT merumuskan strategi yang diterapkan agar implementasi kebijakan tentang program Kampung Keluarga Berencana menuju keluarga sejahtera di Kabupaten Cirebon tersebut dapat terwujud.

Langkah-langkah analisis SWOT dilakukan dengan cara sebagai berikut :

1) Mengidentifikasi factor-faktor yang berhubungan dengan implementasi kebijakan program Kampung KB. Selanjutnya faktor-faktor tersebut diklasifikasikan ke dalam faktor internal (kekuatan dan kelemahan) serta faktor eksternal (peluang dan ancaman) yaitu sebagai berikut:

Tabel 1.

Faktor-faktor Yang Berhubungan Dengan Implementasi Kebijakan Program Kampung KB

\begin{tabular}{|c|c|}
\hline Faktor Internal & Faktor Eksternal \\
\hline $\begin{array}{l}\text { Kekuatan (Strength): } \\
\text { 1. Program pemerintah } \\
\text { 2. Mekanisme program } \\
\text { 3. Keterampilan petugas } \\
\text { 4. Manfaat program } \\
\text { 5. Kegiatan bina keluarga }\end{array}$ & $\begin{array}{l}\text { Peluang (Opportunity): } \\
\text { 1. Nilai gotong royong } \\
\text { 2. Pendekatan tokoh } \\
\text { 3. Jumlah penduduk } \\
\text { 4. Kepentingan masyarakat } \\
\text { 5. Dukungan tokoh formal }\end{array}$ \\
\hline $\begin{array}{l}\text { Kelamahan (Weakness) : } \\
\text { 1. Evaluasi dan pelaporan } \\
\text { 2. Pencapaian kontrasepsi } \\
\text { jangka panjang } \\
\text { 3. Koordinasi dengan instansi } \\
\text { terkait } \\
\text { 4. Pengelola KB } \\
\text { 5. Sosialisasi keluarga } \\
\text { sejahtera }\end{array}$ & $\begin{array}{l}\text { Ancaman (Threat) : } \\
\text { 1. Pembinaan institusi } \\
\text { 2. Sarana pendukung } \\
\text { 3. Respon pelaksana terhadap } \\
\text { program } \\
\text { 4. Partisipasi masyarakat } \\
\text { 5. Upaya peningkatan derajat } \\
\text { kesehatan lingkungan }\end{array}$ \\
\hline
\end{tabular}

2) Mementukan bobot, rating dan nilai tiap tiap faktor melalui wawancara, observasi dan $F G D$. Setelah diketahui, maka ditemtukan evaluasi faktor kekuatan, kelemahan, peluang maupun ancaman yang mungkin terjadi dengan tabel berikut: 
Tabel 2.

Matriks Evaluasi Faktor Internal / IFE

\begin{tabular}{|c|c|c|c|}
\hline Faktor Internal & Bobot & Rating & Nilai \\
\hline \multicolumn{4}{|l|}{ Kekuatan / Strengths $(\mathrm{S})$ : } \\
\hline 1. Program Pemerintah & 0,21 & 4 & 0,84 \\
\hline 2. Mekanisme Program & 0,21 & 4 & 0,84 \\
\hline 2. Keterampilan Petugas & 0,16 & 3 & 0,48 \\
\hline 3. Manfaat Program & 0,26 & 5 & 1,30 \\
\hline 4. Kegiatan Bina Keluarga & 0,16 & 3 & 0,48 \\
\hline Jumlah (S) & $\mathbf{1 , 0 0}$ & & 3,94 \\
\hline \multicolumn{4}{|l|}{ Kelemahan /Weakness (W) : } \\
\hline 1. Evaluasi dan Pelaporan & 0,14 & 2 & 0,28 \\
\hline $\begin{array}{l}\text { 2. Capaian Kontrasepsi } \\
\text { Jangka Panjang } \\
\end{array}$ & 0,14 & 2 & 0,28 \\
\hline $\begin{array}{l}\text { 3. Koordinasi dengan } \\
\text { Instansi Terkait }\end{array}$ & 0,21 & 3 & 0,63 \\
\hline 4. Pengelola KB & 0,22 & 3 & 0,66 \\
\hline $\begin{array}{l}\text { 5. Sosialisasi Seluarga } \\
\text { Sejahtera }\end{array}$ & 0,29 & 4 & 1,16 \\
\hline Jumlah (W) & 1,00 & & 3,01 \\
\hline
\end{tabular}

Sumber: Hasil Penelitian, Wawancara, Observasi dan FGD Tahun 2017

Tabel 3.

Matriks Evaluasi Faktor Eksternal / EFE

\begin{tabular}{|c|c|c|c|}
\hline Faktor Eksternal & Bobot & Rating & Nilai \\
\hline Peluang/Opportunities (O) : & & & \\
\hline 1. Nilai Gotong Royong & 0,25 & 4 & 1,00 \\
\hline 2. Pendekatan Tokoh & 0,19 & 3 & 0,57 \\
\hline 3. Jumlah Penduduk & 0,12 & 2 & 0,24 \\
\hline 4. kepentingan Masyarakat & 0,19 & 3 & 0,57 \\
\hline 5. Dukungan Tokoh Formal & 0,25 & 4 & 1,00 \\
\hline Jumlah (O) & $\mathbf{1 , 0 0}$ & & $\mathbf{3 , 3 8}$ \\
\hline $\begin{array}{c}\text { Ancaman / Threats (T) : } \\
\text { 1. Pembinaan Institusi }\end{array}$ & 0,17 & 3 & 0,51 \\
\hline 2. Sarana Pendukung & 0,22 & 4 & 1,88 \\
\hline $\begin{array}{c}\text { 3. Respon Pelaksana } \\
\text { Terhadap Program }\end{array}$ & 0,28 & 5 & 1,40 \\
\hline 4. Partisipasi Masyarakat & 0,17 & 3 & 0,51 \\
\hline $\begin{array}{c}\text { 5. Upaya Peningkatan erajat } \\
\text { Kesehatan Lingkungan }\end{array}$ & 0,16 & 3 & 0,40 \\
\hline $\begin{array}{l}\text { Jumlah (T) } \\
\text { (1,00 }\end{array}$ & & $\mathbf{3 , 7 8}$ \\
\hline
\end{tabular}

Sumber: Hasil Penelitian, Wawancara, Observasi dan FGD Tahun 2017

3) Penempatan ordinat perhitungan kumulatif nilai tiap faktor internal maupun faktor eksternal yang sebelumnya telah dihitung yaitu hasil dari strength posture dan competitive posture.
Berdasarkan perhitungan sebelumnya diketahui :

$\begin{array}{lll}\text { Jumlah S (Strength) } & = & 3,94 \\ \text { Jumlah W (Weakness) } & = & -3,01 \\ & & \\ \text { Jumlah O (Opportunity) } & = & 3,38\end{array}$




$\begin{array}{llr}\text { Jumlah T (Threat) } & = & -3,78 \\ \text { Stength Posture } & = & 0,93 \\ \text { Competitive Posture } & = & -0,40\end{array}$

4) Menentukan titik ordinat yaitu titik pertemuan antara nilai Strength Posture (0,93) dengan nilai Competitive Postur (-0,40), kemudian menarik garis dari 0 ke titik ordinat tersebut.

Berdasarkan langkah-langkah dan nilainilai di atas, maka dapat digambarkan kuadran SWOT-nya yaitu sebagai berikut:

Hasil Analisis / Kuadran SWOT

Strategi Implementasi Kabijakan Program Kampung KB

Gambar 3. : Hasil Analisis SWOT

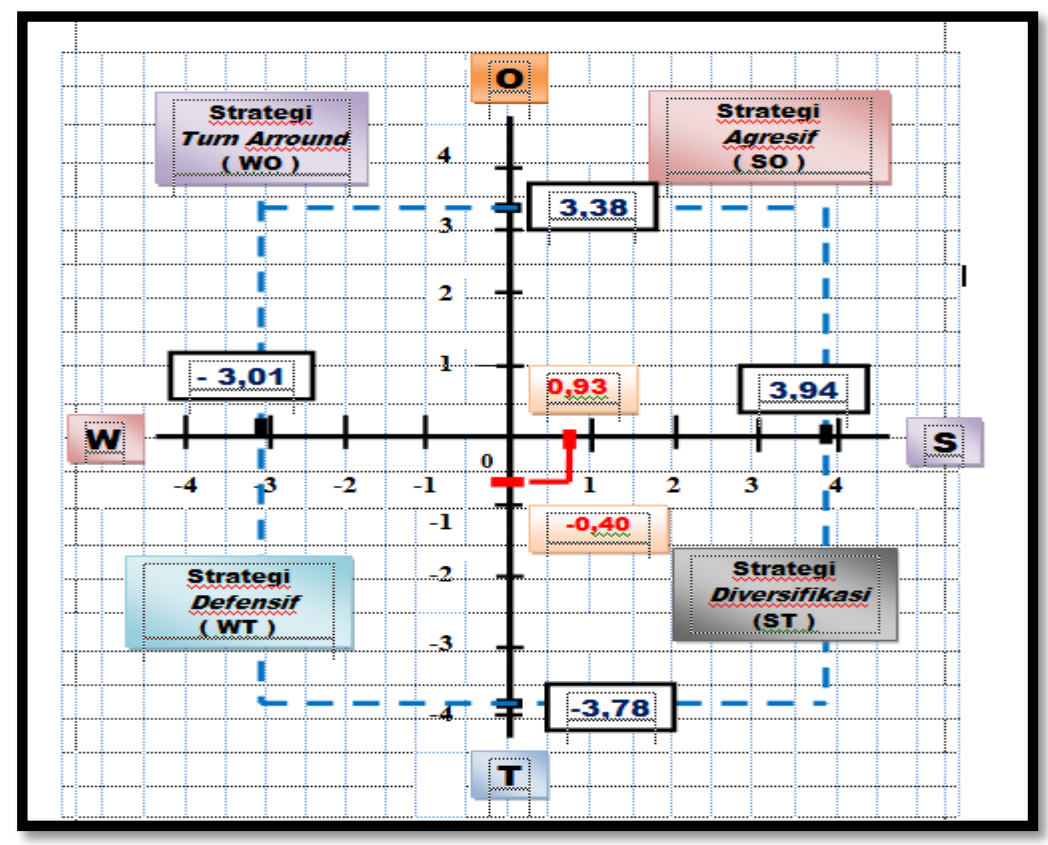

Sumber: Hasil Penelitian Tahun 2017

Strategi Yang Efektif Untuk Mengoptimalkan Implementasi Kebijakan Tentang Program Kampung KB Menuju Terwujudnya Keluarga Sejahtera di Kabupaten Cirebon.

Strategi yang tepat dan efektif, berdasarkan analisis dan gambar kuadran SWOT diatas, daerah terluas dari titik ordinat terletak pada kuadran 2. Strategi yang harus diterapkan dalam kondisi ini adalah mendukung kebijakan Diversifikasi Konsentris. Strategi ini disebut juga Strategi ST (Strength - Threat) yaitu strategi yang menggunakan kekuatan untuk mengatasi ancaman.

Berdasarkan kekuatan (S) dan ancaman (T) tersebut, maka dapat dibuat matriks strategi ST yaitu sebagai berikut: 


\section{Strategi ST \\ Untuk Implementasi Kebijakan \\ Tentang Program Kampung Keluarga Berencana}

Tabel .4.

\begin{tabular}{|c|c|c|c|c|c|c|}
\hline & JFAS & \multicolumn{5}{|c|}{ KEKUATAN (STRENGTH) - S } \\
\hline \multirow{2}{*}{\multicolumn{2}{|c|}{$\begin{array}{l}\text { EFAS } \\
\text { (THCAREAT) - T }\end{array}$}} & 1 & \begin{tabular}{|l|l}
2 &
\end{tabular} & 3 & 4 & 5 \\
\hline & & $\begin{array}{l}\text { Program } \\
\text { pemerintah }\end{array}$ & $\begin{array}{c}\text { Mekanisme } \\
\text { program }\end{array}$ & $\begin{array}{c}\text { Keterampilan } \\
\text { petugas }\end{array}$ & $\begin{array}{l}\text { Manfaat } \\
\text { program }\end{array}$ & $\begin{array}{l}\text { Kegiatan bina } \\
\text { keluarga }\end{array}$ \\
\hline 1 & $\begin{array}{l}\text { Pembinaan } \\
\text { institusi }\end{array}$ & \multirow{5}{*}{\multicolumn{5}{|c|}{$\begin{array}{l}\text { STRATEGI S - T : } \\
\text { 1. Mengoptimalkan kemempuan dan keterampilan melalui mekanisme } \\
\text { yang utuh untuk mengoptimalkan pembinaan institusi masyarakat } \\
\text { secara berkesinambungan. } \\
\text { 2. Pengadaan sarana pendukung yang memadai untuk program Kampung } \\
\text { KB yang merupakan program unggulan dari Pemerintah Kabupaten } \\
\text { Cirebon. } \\
\text { 3. Mengoptimalkan kegiatan bina keluarga didukung oleh respon dari } \\
\text { pelaksana program dalam mewujudkan keluarga yang sejahtera. } \\
\text { 4. Menumbuhkan partisipasi masyarakat melalui metode musyawarah } \\
\text { partisipatif dalam menentukan kebutuhan atau kepentingan } \\
\text { masyarakat untuk dapat menumbuhkan partisipasi masyarakat dalam } \\
\text { meningkatkan derajat kesehatan lingkungan. }\end{array}$}} \\
\hline 2 & $\begin{array}{l}\text { Sarana } \\
\text { pendukung }\end{array}$ & & & & & \\
\hline 3 & $\begin{array}{l}\text { Respon } \\
\text { pelaksana } \\
\text { terhadap } \\
\text { program }\end{array}$ & & & & & \\
\hline 4 & $\begin{array}{l}\text { Partisipasi } \\
\text { masyarakat }\end{array}$ & & & & & \\
\hline 5 & $\begin{array}{l}\text { Upaya } \\
\text { peningkatan } \\
\text { derajat } \\
\text { kesehatan } \\
\text { lingkungan }\end{array}$ & & & & & \\
\hline
\end{tabular}

Sumber : Hasil Penelitian dan FGD Tahun 2017

Berdasarkan pada tabel diatas, maka rekomendasi yang diberikan adalah cenderung ke Strategi Diversifikasi (ST) dimana strategi ini menciptakan strategi yang menggunakan kekuatan untuk mengatasi ancaman. Strategi diversifikasi konsentris, yaitu tindakan untuk membuat sesuatu lebih beragam tidak terpaku pada satu jenis :

\section{1) Mengoptimalkan kemampuan} dan keterampilan melelui mekanisme program dengan utuh untuk mengoptimalkan pembinaan institusi masyarakat secara berkesinambungan.

Kegiatan yang dilakukan adalah pembinaan institusi masyarakat dengan kemempuan dan keterampilan secara berkesinambungan melalui mekanisme kegiatan yang ada. Kegiatan itu dilakukan agar institusi masyarakat dapat memahami dan mengerti apa yang dilakukan oleh Pokja Kampung
KB. Bentuk kegiatan pembinaan berupa kunjungan langsung ke institusi, pertemuan-pertemuan secara rutin ataupun pelaksanaan pelatihan-pelatihan terhadap institusi masyarakat dalam bidang KB dan keluarga sejahtera maupun pelatihan tentang bina keluarga dan penggunaan kontrasepsi MJP.

2) Program Kampung KB sebagai program unggulan pemerintah, harus ditunjang dengan sarana pendukung yang optimal

Sebagaimana yang tertuang dalam Undang-undang Nomor 52 Tahun 2009 tentang perkembangan kependudukan dan pembangunan keluarga serta Peraturan daerah Kabupaten Cirebon Nomor 1 Tahun 2015 tetang RPJMD, bahwa program Kampung KB merupakan salah satu dari program unggulan Pemerintah Kabupaten Cirebon. Pelaksanaan 
kegiatan agar ditunjang oleh sarana pendukung yang memadai dari berbagai stakeholders/instansi terkait yang sudah tertuang dalam Keputusan Bupati Cirebon tentang Tim Koordinasi Pembentukan Kampung KB di Kabupaten Cirebon.

3) Mengoptimalkan kegiatan bina keluarga didukung oleh peningkatan respon dari pelaksana program dalam mewujudkan keluarga sejahtera.

Bina keluarga merupakan wadah kegiatan dari semua keluarga yang mempunya balita, remaja dan lansia. Yang perlu diketahui dalam kegiatan bina keluarga ini adalah kegiatannya bukan ditujukan untuk balita, remaja dan lansianya, tetapi lebih diutamakan pembinaan terhadap keluargakeluarga yang mempunyai balita, remaja dan lansia.

Adanya kegiatan bina keluarga, para keluarga akan dapat mengerti tentang 8 fungsi keluarga, keluarga berencana, kesehatan, kesejahteraan keluarga dan kegiatan lainnya.

4) Menumbuhkan partisipasi masyarakat melalui metode musyawarah partisipatif dalam menentukan kegiatan atau kepentingan masyarakat untuk dapat menumbuhkan partisipasi dalam meningkatkan derajat kesehatan lingkungan.

Kegiatan ini dilakukan agar lingkungan tidak jadi kumuh /tidak beraturan, akses transfortasi diharapkan bisa dilalui oleh kendaraan roda dua atau roda tiga, karena masih terdapat di beberapa wilayah yang jalan atau gang tidak dapat dilalui oleh kendaraan roda tiga (beca). Berdasarkan uraian diatas, faktor-faktor yang mempengaruhi implementasi kebijakan yang dikemukakan oleh Grindle, yaitu faktor content of policy (isi kebijakan) dan faktor contexs of implementation (konteks implementasi), lebih banyak berkaitan dengan pelaksana program, kepentingan, manfaat, sumber daya.

Temuan penelitian/novelty di Kabupaten Cirebon, yang mempunyai kultur dan kondisi wilayah berbeda dengan daerah lain ditemukan beberapa faktor yang mempengaruhi sebuh kebijakan, khususnya kebijakan tentang program Kampung KB, disamping dari Teori Grindle (1980) serta dari hasil analisis penelitian terdahulu, faktor lain yang mempengaruhi kebijakan tentang program Kampung $\mathrm{KB}$ menuju terwujudnya keluarga sejahtera di Kabupaten Cirebon antara lain yaitu sinergitas kelembagaan (institutional synergies), kekuatan agama dan budaya (religious and cultural forces) dan pemberdayaan masyarakat (community empowerment).

Ketiga dimensi tersebut menurut peneliti mempunyai pengaruh yang sangat penting dalam mewujudkan keberhasilan implementasi kebijakan tentang program Kampung Keluarga Berencana menuju terwujudnya keluarga sejahtera di Kabupaten Cirebon. Ketiga dimensi tersebut belum tercantum dalam model implementasi kebijakan Grindle. Nampaknya Grindle mengabaikan ke tiga dimensi penting yang diperlukan dalam implementasi kebijakan publik.

Memanfaatkan

Sinergitas kelembagaan melalui kekuatan agama dan budaya dengan efektif untuk 
meningkatkan

pemberdayaan masyarakat akan menjadikan kebijakan program Kampung di kabupaten Cirebon dapat berjalan secara efektif.

Lebih jelasnya ketiga dimensi hasil temuan penelitian/novelty dilapangan dapat diuraikan sebagai berikut :

\section{1). Sinergitas Kelembagaan (institutional synergies)}

Sinergitas merupakan proses memadukan beberapa aktivitas dalam rangka mencapai satu hasil yang berlipat atau dalam kata lain kerja sama atau kombinasi unsur yang dapat menghasilkan hasil yang lebih baik, sinergitas dapat terbangun melalui dua cara yaitu 1) komunikasi dan 2) koordinasi. Sinergitas adalah gabungan atau kerja sama yang dilakukan guna mendapatkan hasil yang lebih maksimal dengan terhubung oleh beberapa peran yang berbeda namun terkait didalamnya.

Sinergitas kelembagaan di tingkat Desa mencakup BPD, LPMD, Pemerintah Desa, RW, RW, Karang Taruna, MUI, PKK dan lembaga lainnya dikoordinasikan oleh Kepala Desa/Kuwu untuk bersama-sama melakukankegiatan program Kampung KB.

\section{2). Kekuatan Agama dan Budaya (Religious and Cultural Forces)}

Budaya merupakan keseluruhan sistem, gagasan tindakan dan hasil kerja manusia dalam rangka kehidupan masyarakat. jadi budaya diperoleh melalui belajar. Konsep budaya menurut Turmudzi menyatakan bahwa istilah budaya dapat diartikan sebagai : 1). fikiran, akal budi, hasil 2). Adat istiadat, 3). Sesuatu mengenai kebudayaan yang sudah berkembang, Sedangkan agama merupakan aturan yang datangnya dari Tuhan/Allah.

Dilihat dari fungsinya budaya merupakan hal yang mendasar yang ada dalam diri setiap orang. Kepada agama setiap orang mempunyai kewajiban yang harus dijalankan dan larangan yang harus ditinggalkan sedangkan adat-istiadat merupakan aturan yang telah berlaku turun temurun.

Kabupaten Cirebon merupakan daerah yang agamis yang artinya masih mempunyai dan menjaga nilai nilai agama yang dianut dalam hal ini nilainilai agama Islam. Selain itu juga masih patuh terhadap kearifan budaya lokal atau nilai-nilai adat yang berlaku. Implementasi kebijakan tentang program Kampung KB, selain kegiatan tentang peningkatan pencapaian peserta KB jangka panjang juga kegiatan bina keluarga maupun penataan lingkungan. Menyikapi kegiatan penataan lingkungan, di Kabupaten Cirebon sebagian besar akan dapat berhasil apabila dilakukan pendekatan ke tokoh adat, kekuatan adat dalam membangun partisipasi masyarakat dan nilai gotong royong masih sangat besar.

Pendekatan ke tokoh agama maupun ke tokoh adat pada setiap daerah sangat berbeda, ada cenderung yang berpengaruh adalah tokoh agama, ada juga cenderung yang berpengaruh adalah tokoh adat. Apabila tokoh agama dan tokoh adat dimanfaatkan untuk kegiatan implementasi kebijakan tentang program Kampung KB menuju keluarga sejahtera di Kabupaten Cirebon akan terwujudnya.

\section{3) Pemberdayaan Masyarakat (Community Empowerment)}

Konsep pemberdayaan masyarakat menurut Word Bank adalah sebagai upaya untuk memberikan kesempatan dan kemampuan kepada kelompok masyarakat untuk mampu dan berani bersuara atau menyuarakan pendapat, ide atau gagasan-gagasannya serta kemampuan untuk memilih sesuatu (konsep, metode, produk, tindakan dan lain-lain) yang terbaik bagi pribadi, keluarga dan masyarakatnya. Konsep tersebut menitik beratkan pada 
pemberian kesempatan untuk dapat menyampaikan pendapat dan kemampuannya dalam memilih sesuatu yang dapat bermanfaat bagi diri dan masyarakatnya.

Proses pemberdayaan adalah menfasilitasi masyarakat untuk mengkaji kebutuhan, masalah dan peluang pembangunan dan

\subsection{KESIMPULAN DAN REKOMENDASI}

\section{Kesimpulan}

Berdasarkan hasil penelitian dan pembahasan yang sudah diuraikan pada Bab sebelumnya, maka ada beberapa hal yang dapat disimpulkan dalam penelitian dengan menghasilkan beberapa temuan penelitian adalah sebagai berikut :

1) Implementasi kebijakan tentang program Kampung KB menuju keluarga sejahtera di Kabupaten Cirebon belum terwujudnya baik dalam perencanaan, pelaksanaan maupun evaluasi dan pelaporan. Faktor-faktor yang menyebabkan implementasi kebijakan tentang program Kampung KB menuju keluarga yang sejahtera di Kabupaten Cirebon belum terwujudnya, dilihat dari faktor content of policy (isi kebijkan) adalah sebagai berikut :

a. Kurang adanya upaya terhadap penataan lingkungan dan rutilahu;

b. Pencapaian peserta KB MJP masih rendah;

c. Kegiatan bina keluarga belum maksimal;

d. Kurang dilakukannya evaluasi dan pelaporan program Kampung KB;

e. Koordinasi dengan instansi terkait masih belum maksimal;

f. Tenaga pengelola/penyuluh KB kurang memadai perikehidupan mereka sendiri serta agar dapat menemukan solusi yang tepat dan dapat mengakses sumber daya yang diperlukan bersumber dari yang dimiliki masyarakat itu sendiri. Timbulnya kesadaran masyarakat untuk membagun wilayahnya, merupakan modal dasar yang sangat besar dalam mewujudkan keluarga yang sejahtera.

g. Kegiatan Pokja Kampung KB belum maksimal;

h. Partisipasi masyarakat tidak optimal;

i. Terbatasnya sarana pendukung. Faktor Context of implementation (konteks implementasi) adalah sebagai berikut :

a. Pembinaan terhadap institusi tidak berkesinambungan;

b. Kurangnya sosialisasi keluarga sejahtera;

c. Respon pelaksana terhadap program Kampung KB kurang optimal;

Faktor selain content of policy (isi kebijkan) dan faktor Context of implementation (konteks implementasi) yang mempengaruhi implementsi kebijakan secara signifikan dari hasil penelitian, wawancara, observasi dan $F G D$ adalah faktor Sinergitas kelembagaan (institutional synergies) kekuatan agama dan budaya (religious and cultural forces) dan pemberdayaan masyarakat (community empowerment) merupakan faktor penting dalam implementasi kebijakan.

2) Strategi yang paling tepat berdasarkan hasil penelitian dan analisis adalah cenderung ke Strategi Deversifikasi konsentris yaitu tindakan untuk membuat sesuatu lebih beragam, tidak terpaku pada satu jenis program atau disebut juga Strategi ST, dimana dalam strategi ini menggunakan

Kekuatan (Strengths) untuk mengatasi 
Ancaman (Threat) yang dihadapi yaitu dengan cara :

a. Mengoptimalkan kemempuan dan keterampilan melalui mekanisme program secara utuh untuk mengoptimalkan pembinaan institusi secara berkesinambungan.

b. Pengadaan sarana pendukung yang memadai untuk mendukung program unggulan Pemerintah Daerah yaitu program Kampung KB.

c. Mengoptimalkan kegiatan bina keluarga didukung oleh respon dan daya tanggap dari pelaksana program dalam mewujudkan keluarga yang sejahtera.

d. Menumbuhkan partisipasi masyarakat melalui metode musyawarah partisipatif dalam menentukan kebutuhan atau kepentingan masyarakat untuk dapat menumbuhkan partisipasi peningkatan kesehatan lingkungan.

\section{Rekomendasi}

Peneliti merekomendasikan suatu adaptasi model implementasi kebijakan yang dikemukakan oleh Grindle dengan menambahkan tiga dimensi yaitu sinergitas kelembagaan (institutional

\section{Daftar Pustaka}

\section{A. Buku-Buku}

Alamsyah, Kamal 2009. Reformasi Administrasi Republik Indonesia. Pascasarjana Unpas, Bandung.

Ali Faried dan Alam Syamsu Andi, 2012. Studi Kebijakan Pemerintah.

Refika Aditama, Bandung.

Anggara, 2014. Kebijakan Publik. Pustaka Setia, Bandung.

Betra, Vijay dan Arora Divya dan Batra Promod, 2000. Merakit synergies) dimasukkan kedalam faktor isi kebijakan, kekuatan agama dan budaya (religious and cultural forces), dan pemberdayaan masyarakat (community empowerment) dimasukkan kedalam faktor konteks implementasi, sebagai dimensi yang juga menentukan keberhasilan suatu implementasi kebijakan. Penambahan tiga dimensi ke dalam faktor tersebut, maka outcomes yang dikemukakan oleh Grindle dapat dicapai sesuai tujuan. Adaptasi/pembaruan model implementasi kebijakan yang dikemukakan oleh Grindle tersebut dapat digambarkan sebagai berikut:

Gambar 4.5. : Adaptasi/Pembaruan Model Implementasi Kebijakan Grindle

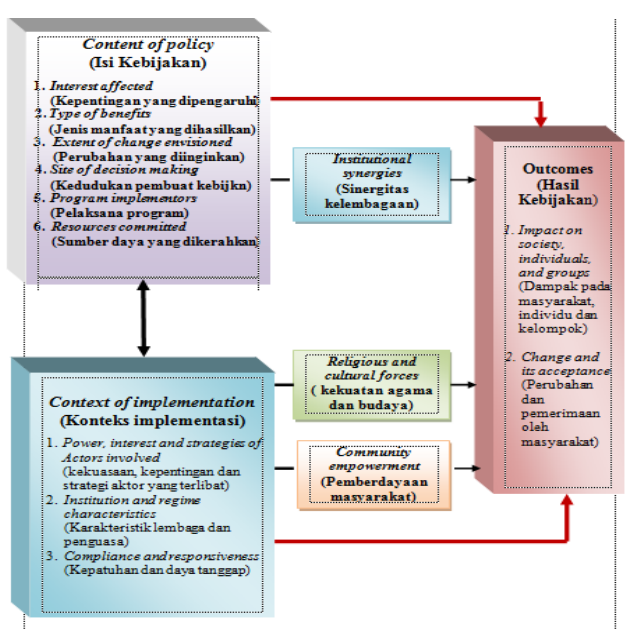

Sumber: Hasil Penelitian Tahun 2017

dan Membina Keluarga

Bahagia. Nuansa, Bandung.

BKKBN, $1996 . \quad$ Pedoman

Pengelolaan Balai Mitra

Sejahtera (BKM). Deputi

Bidang Keluarga Sejahtera,

Jakarta.

------------, 2003. Pedoman Kerja

PLKB dalam Menghadapi

Perubahan. Deputi Bidang

Keluarga Sejahtera, Jakarta.

- 2014. $\quad$ Pedoman

Pengelolaan dan Pengembangan 
Kelompok Usaha Peningkatan Pendapatan Keluarga Sejahtera (UPPKS). Dirjen Pemberdayaan Ekonomi Keluarga, Jakarta.

Cangara, 2005. Pengantar Ilmu Komunikasi. Grafindo Persada, Jakarta.

Creswell, W. John, 2013. Research Design Pendekatan Kualitatif, Kuantitatif dan Mixed. Pustaka Pelajar, Yogyakarta.

Dunn, N. Willian, 2010. Pengantar Analisa Kebijakan Publik. Gajah Mada University Press, Yogyakarta.

Edward III, C. George, 1980. Implementing Public Policy. Congressional. Quarterly INC, Washington DC.

Fischer, Frank and Miller, Gerald and Sidney, Mara, 2007. Handbook Of Public Policy Analysis. CRS, USA

Effendy, Onong, 1981. Dimensidimensi Komunikasi. Alumni, Bandung.

Grindle, 1981. Politic and Policy Implementation in the Third World. University Press, New Jersey.

Handayaningrat, Suwarno, 1990. Pengantar Studi Ilmu Administrasi dan Manajemen. Haji Masagung, Jakarta.

Hanggraeni, Dewi, 2011. Perilaku Organisasi. Fakulkas Ekonomi UI, Jakarta.

Husni, ZA. Ipin, 2015. Kampung KB: Pencanangan dan Pembentukan. Biro Perencanaan BKKBN, Jakarta.

Islamy, Irfan, 2014. Prinsip-prinsip Perumusan Kabijaksanaan Negara. Bumi Aksara, Jakarta.

Kabupaten Cirebon, 2016. Kabupaten Cirebon Dalam Angka. BPS, Kabupaten Cirebon
Kartasasmita, Ginandjar, 1996. Pembangunan Untuk Rakyat. CIDES, Jakarta.

1997. Administrasi
Pembangunan. Pustaka LP3ES,
Jakarta.
Keban, 2008. Administrasi Publik. Gavamedia, Yogyakarta.

Mahmudi, 2010. Manajemen Kinerja Sektor Publik. STIM-YKPN, Yogyakarta.

Mardikanto, Totokdan Soebiato, Poerwoko, 2015. Pemberdayaan Masyarakat dalam Perspektif Kebijakan Publik. Alfabeta, Bandung

Mazmanian, Daniel and Sabatier, Paul, 1983. Implementation and Public Foresman and Company, USA.

Moleonag, J. Lext, 2011. Metodologi Penelitian Kualitatif. Remaja Rosdakarya, Bandung

Mulyadi, 2015. Studi Kebijakan Publik dan Pelayanan Publik. Alfabeta, Bandung.

Mulyana, Rakhmat, 2010. Komunikasi Antar Budaya. Rordakarya, Bandung

Nugroho, Riant, 2014. Public Policy. Gramedia, Jakarta.

O'Leary, Elizabeth, 2002. Kepemimpinan, Menguasai Keahlian yang Anda Perlukan. Andi, Yogyakarta.

Osborne, David and Geabler, Ted, 1999. Mewirausahakan Birokrasi. Pustaka Binaman Pressindo, Jakarta.

Purwanto, Agus, Erwan dan Sulistyastuti, Diah, 2012. Implementasi Kebijakan Publik. Gava Media, Yogyakarta.

Rachmat, 2014. Manajemen Strategik. Pustaka Setia, Bandung

Rangkuti, Freddy, 2016. Analisis SWOT Tehnik Membedah Kasus Bisnis. Gramedia, Jakarta. 
Robbins, D. Stephen ,2003. Perilaku Organisasi. Indeks Gramedia, Jakarta.

Rusli, Budiman, 2015. Kebijakan Publik. Adoya Mitra Sejahtera, Bandung.

Sedarmayanti, 2002. Metodologi Penelitian. Mandar Maju, Bandung

-------------, 2003. Good Governance. Mandar Maju, Bandung. ------------, 2007. Manajemen SDM. Refika Aditama., Bandung.

Siagian, Sondang, 2006. Filsafat Administrasi. Bumi Aksara, Jakarta.

--------------, 2012. Teori Motivasi dan Aplikasinya. Rineka Cipta, Jakarta.

Sugandha, Dann, 1988. Koordinasi. Intermedia, Jakarta.

Sugiyono, 2002. Metode Penelitian Administrasi. Alfabeta, Bandung.

------------, 2015. Metode Penelitian Kombinasi (Mixed Methods). Alfabeta, Bandung

Suharto, Edi, 2013. Kemiskinan\&Perlindungan Sosial di Indonesia. Alfabeta, Bandung.

Suranto, 2011. Komunikasi Interpersonal. Graha Ilmu, Yogyakarta.

Surya, Muhammad, 2003. Psikologi Konseling. Pustaka Beni Quraisy, Bandung

Syafiie, Kencana, Inu, 2010. Ilmu Administrasi Publik. Rineka Cipta, Jakarta.

Thoha, Miftah, 2008. Ilmu Administrasi Publik Kontemporer. Prenada Media, Jakarta.

--------, 2014. Birokrasi \& Dinamika Kekuasaan. Prenada Media, Jakarta.

2014. Birokrasi Politik. Prenada Media, Jakarta.
Turmudzi, Didi, 2013. Budaya Organisasi. Prisma Press, Bandung.

Wheelen L, Thomas end Hunger David. J, 2016. Manajemen Strategis. Andi, Yogyakarta.

Winarno, Budi, 2012. Kebijakan Publik. CAPS, Yogyakarta.

\section{B. Dokumen}

Ambarwati, Nur, Winarsih, 2011. Hubungan Antara Pengeratuan dengan Sikap Motivasi Suami dalam Keluarga Berencana di Kabupaten Sragen. Jurnal, PPNI Jawa Tengah (http://jurnalunimus.ac.id)

Hamudi, Ilham, Moh, 2015. Institutional Formation of Family Planning in the District Sukabumi and the Bitung. Jurnal, BPP Kemendagrai (http:// downlod.portalgaruda.org)

Istiadah, 2010. Makna Keluarga Berencana Bagi Perempuan Muslim di Temas Batu Jawa Timur. Disertasi, UIIS Malang.

Patra, Shraboni and Singh, Kumar, Rakesh, 2014. Addresing unmet need and religious barrier to words the use of family planning method among muslim in India. Senior Research University of International, Mumbai India. Jurnal Internasional (http://www.emeraldinsight.com/d oi/ 101108/ IJHRH-00-20140010).

Pemerintah Kabupaten Cirebon, 2015. Rapat Kerja Daerah Program Kependudukan, KB dan Pemberdayaan Perempuan Tahun 2015.

Pemerintah Kabupaten Cirebon, 2017. Rapat Kerja Daerah Program Kependudukan, KB dan Pemberdayaan Perempuan Tahun 2017. 
Soenarnatalina, 2016. Pengembangan Indeks Keluarga Sejahtera di Provinsi Jawa Timur. Disertasi, Universitas Airlangga, Surabaya.

Suandi, 2007. Hubungan Antara Karakteristik Rumah Tangga dengan Partisipasi dalam Keluarga Berencana di Provinsi Jambi. Jurnal SDKI, Universitas. Jambi (https://www.jurnalasia.com/sere moni/2007).

Sukaesih, Ade, 2015. Pengaruh Birokrasi dan Disiplin Kerja Terhadap Kualitas Pelayanan pada Badan KB dan Pemberdayaan Perempuan di Kabupaten dan Kota Wilayah Priangan Timur Provinsi Jawa Barat. Disertasi, Unpas Bandung.

Syarif, Sugiri, 2012. Pengaruh Implementasi Kabijakan Keluarga Berencana Terhadap Pemberdayaan Masyarakat di Kabupaten Way Kanan Lampung. Disertasi, Unpad Bandung

Wang, Guojun, 2015. The life security system for Chinese families in compliance with the family planning policy. Universitiy of International Business and Economics, Beijing. Jurnal Internasional (http://www.emeraldinsight.com/d oi/pdfplus/10.1108/15265941211 229253)

\section{Peraturan} undangan

Republik Indonesia, 1992. Undang undang Nomor 10 Tahun 1992 tentang Perkembangan Kependudukan dan Pembangunan Keluarga Sejahtera.

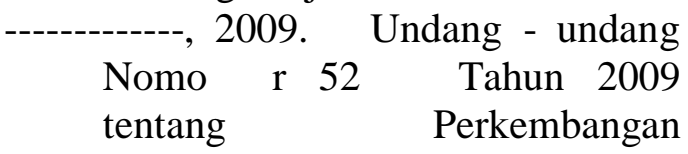

Kependudukan dan Pembangunan Keluarga.

----------, 2014. Undang-undang

Dasar 1945. Sendang Ilmu, Solo , Undang-undang Nomor 23

Tahun 2014 tentang Pemerintahan Daerah. Fokusindo Mandiri, Bandung

Pemerintah Kabupaten Cirebon, 2015. Peraturan Daerah Kabupaten Cirebon Nomor 4 Tahun 2015 tentang RPJMD.

Pemerintah Kabupaten Cirebon, 2012. Peraturan Daerah Kabupaten Cirebon Nomor 7 Tahun 2012 tentang Pengelolaan Sampah.

-----------, 2016. Peraturan Bupati Cirebon Nomor 73 Tahun 2016 tentang Fungsi, Tugas Pokok dan Tata Kerja Dinas Pengendalian Penduduk, KB, Pemberdayaan Perempuan dan Perlindungan Anak.

Cirebon Nomor 476/Kep.364-
BPPKB/ 2015

